\title{
A Contrastive Critical Discourse Analysis of Netanyahu's and Abbas's Speeches on the Gaza War (2014)
}

\author{
Alaa' G. Rababah \\ The University of Jordan, Amman, Jordan \\ Jihad M. Hamdan \\ The University of Jordan, Amman, Jordan
}

\begin{abstract}
This study provides a contrastive critical discourse analysis of the speeches of the Israeli Prime minister Benjamin Netanyahu and the Palestinian President Mahmoud Abbas to the United Nations General Assembly regarding the Gaza War (2014). The analysis explores the representation of the "Self" and the "Other" in relation to the war. Van Dijk's 'Ideological Square' theory is adopted to explore the group polarization of Us versus Them dichotomy. Moreover Halliday's Systematic Functional Grammar is utilized in the analysis to study how the polarization of the "Self" and "Other" is constructed via particular grammatical transitivity choices. The results indicated that the representation of the "Self" and "Other" in the speeches reflects two different opposing ideologically-governed perspectives on the Gaza conflict. Both speakers present the "Self" as 'strong', 'human' and 'honorable' in contrast to the "Other" that is deemed to be a 'dire threat' and an 'agent of destruction'.
\end{abstract}

Index Terms - Gaza War, ideology, ideological square, transitivity structures

\section{INTRODUCTION}

The Gaza conflict is considered as one of the most intractable within the wider Israeli-Palestinian conflict. The root of this conflict dates back to the Arab-Israeli War in 1948 which resulted into the Israeli control over the land and the expulsion of thousands of Palestinians from their homes (Masalha, 1992). After the end of the war, thousands of the Palestinians who fled their homes inhabited Gaza, a tiny stripe on the Mediterranean. Gaza was first controlled by Egypt. However, Israel occupied Gaza after another war in 1967. Gaza remained completely under the Israeli control until 1994 when an Israeli withdrawal from Gaza took place after the Palestinian-Israeli peace agreements known as 'the Oslo Accords'. Israel transferred governmental authority to the Palestinians but with limited control. A power struggle has arisen then between the two main political Palestinian factions, Fatah and Hamas, resulting into a split in the Palestinian authority (Wikipedia, 2018). The conflict between Hamas and Fatah intensified after Hamas won the elections of 2006. Gaza then became a self-governing territory controlled by Hamas. Hamas refused to recognize Israel's seized power in Palestine and rejected previous agreements with Israel (BBC, 2015). Consequently, Israel held Gaza under a blockade leading to drastic reduction of food and medical supplies (Sanger, 2011). Tensions between Hamas and Israel intensified leading to three main wars in the years 2008, 2012 and 2014. Following the outbreak of the third war which Israel waged against Gaza in 2014, thousands of Palestinians were killed and many more injured. On the Israeli side, 66 soldiers and 5 civilians were killed. Accordingly, the Human Rights Watch urged the Human Rights Council to investigate the violations by both sides to identify those responsible for the crimes. The Human Rights Council identified the attacks by both Israel and Hamas as war crimes (Wikipedia, 2015). Such outbreaks led to various speeches regarding the Gaza conflict in front of the United Nations.

Drawing on Critical Discourse Analysis as its general theoretical framework of analysis, this study aims at providing a contrastive analysis of two political speeches- one given by the Israeli Prime Minister, Benjamin Netanyahu and the other by the Palestinian President Mahmoud Abbas regarding this conflict in the year 2014. These speeches are part of the general debate of the $69^{\text {th }}$ session of the United Nations General Assembly in which the two politicians highlighted their standpoints regarding the Gaza War (2014) to elicit support for their positions from the international community.

The study draws on both van Dijk's 'Ideological Square' theory and Halliday's Systematic Functional Grammar (SFG) to show how the different discourses in the speeches embody different ideologically governed opinions towards this conflict. The study, in particular, seeks to answer the following questions:

1. How are the Self/in-group and the Other/out-group represented with regard to the Gaza War (2014) through particular choices in the transitivity structures within the general framework of SFG?

2. How do such specific transitivity choices reflect the ideological standpoints of the speakers? To what extent does the representation of the Self/in-group and the Other/out-group through transitivity structures go in line with van Dijk's 'Ideological Square' theory? 


\section{CRitical Discourse AnAlysis (CDA)}

The crucial role of language in constructing socio-political cognition as well as in expressing, changing and reproducing ideologies has been the focus of many studies in the field of Critical Discourse Analysis (CDA) for so many years. Such an approach provides an insight into the way social power abuse and social dominance are enacted and reproduced by text and talk (van Dijk, 1998, p. 352). It focuses mainly on the relationships between language, power, society, ideology and politics. Within CDA, language is perceived as a mean through which specific ideologies and culture of those groups in power come to dominate a society and social practices. In this context, it is believed that lexical choices can reflect and accentuate the thoughts and the intentions of their users (Fairclough, 1995, p. 210). Thus, language is highly connected with ideology. The main aim of any study in CDA is to analyze those mechanisms and strategies used in a discourse to reveal and unravel the underlying embedded ideologies and agendas connected with it (van Dijk, 1998, p. 352).

In the CDA literature, there has been a large body of research that examined the relationships between language, politics, power and ideology in political speeches. These studies focused on political speeches in a variety of contexts. Some have investigated the US election campaign speeches (Rahimi et al.; 2010; Wang, 2010) and the US presidential speeches within the 'War on Terror' discourse (Rashidi and Souzandehfar 2010; Yu, 2011; Sarfo and Krampa, 2012; Morgan, 2014). Some other studies have analyzed political speeches in an African (Alo, 2012) and in a Pakistani context (Memon et al. 2014; Iqbal, 2015) and. It seems that CDA studies on political speeches related to Middle Eastern issues are limited in scope and number. Within these studies, little emphasis has been given to the political speeches on the Israeli-Palestinian conflict in particular. Relevant studies are based on a single orientation of power and ideology, as they focus in their analysis on the speeches of only one speaker (Ashale, 2013; Nejad et al. 2013). In this way, they present a single ideologically driven view of the conflict.

In view of the foregoing, the study reported here attempts to conduct a contrastive critical discourse analysis on the speeches delivered by the Israeli Prime Minister Benjamin Netanyahu and the Palestinian President Mahmoud Abbas giving a closer exploration of the two opposing ideologies. The study seeks to examine how the conflict is constructed in the speeches and how underlying ideologies are unveiled.

The importance of the study stems from its originality since to the researcher's best knowledge, there has been scarcely any study that has analyzed and contrasted the speeches of top political leaders within the context of the IsraeliPalestinian conflict.

\section{THEORETICAL FRAMEWORK}

\section{A. Van Dijk's 'Ideological Square'}

In his remarkable conceptions of CDA, van Dijk (1997; 1998; 2006) devises a theoretical framework that relates ideology, politics, cognition and discourse. Van Dijk's (1997, 1998, 2001) stresses a cognitive dimension of language use and social practices. Within this approach, cognition is perceived as an interface between social practices and discourse. Cognition is also perceived as mental models or schemata that construct ideological values and attitudes of people. Given the view that such models are ideologically driven mental constructs, they consequently direct the production of discourse and therefore control social practices or actions. In the same vein, discourse through mental models, influences ideologies and enact and reproduce them. It is through discourse that such abstract social beliefs (ideologies) are given an explicit expression and formulation.

Van Dijk's (1997) socio-cognitive approach places a specific focus on Political Discourse Analysis (PDA), which deals the "reproduction of political power, power abuse or domination through political discourse" (p.1). In order to adopt a systematic procedure for conducting an analysis of political discourse, van Dijk (2006) proposes some general strategies that can be applied to different forms of texts and talks including political speeches. He posits that ideological discourse often presents some overall strategies that are called the "Ideological Square" of positive self-presentation (semantic macro-strategy of in-group favoritism) and negative other-presentation (semantic macro-strategy of out-group derogation). These strategies highlight the following:
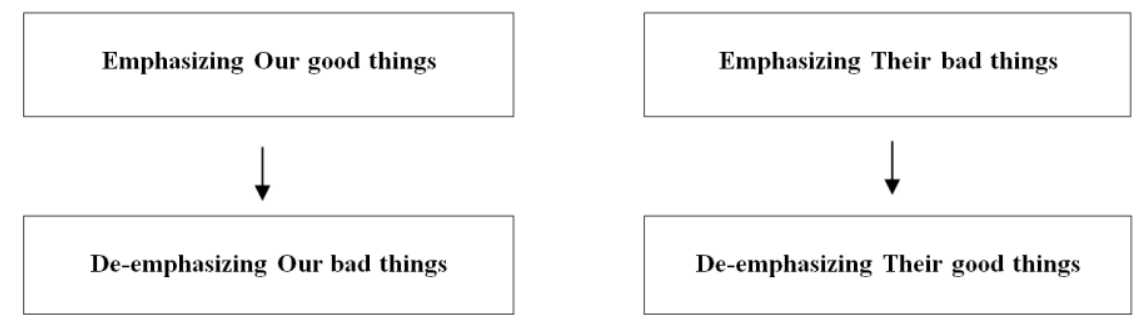

Politicians tend to emphasize all meanings that are positive about themselves and their own group (nation, party, ideology); likewise they tend to highlight all meanings that are negative about the Other. At the same time, they hide and mitigate implicit information that may give themselves a bad impression. 


\section{B. Halliday's Systematic Functional Grammar}

Halliday's Systematic Functional Grammar (SFG) is one of the most substantial theories of language adopted and employed in CDA due to its focus on meaning and the functional aspect of language.

Halliday (1985) offers 'a theory of meaning as choice' which views language as 'networks of interlocking options' from which language users make choices to construct meaning (p. xiv). Accordingly, a systematic choice made for expressing meaning in language is governed by social and cultural contexts and situations. Socio-cultural contexts are a key element in this respect. Halliday's SFG studies language on the basis of the functions it serves in a situational sociocultural context. This language function is referred to as metafunction.

Halliday (1985) proposed three language metafunctions, viz, (1) the ideational, (2) the interpersonal, and the (3) textual metafunction. These functions can provide a useful tool for textual analysis. However, for space limitation the analysis in this study focuses only on the ideational function.

The ideational function presents a clause as a representation. It construes the world of experience. It is through this function that language users express their experiences about the outer objective world around them and the inner subjective world of their consciousness, cognitions and perceptions to describe events, states and entities.

This function is realized by the transitivity structure. In the transitivity structure, a clause is analyzed into (1) a process (verb), (2) the participant(s) involved in the process, and (3) the circumstances associated with the process, e.g. time, space, cause or manner (Halliday, 1985, p.101).

The following is a list of different types of processes through which the structures of transitivity represent experience:

a. Material Processes. These refer to designate processes of acting or performing things. They are realized by an Action Verb (e.g. take, go, give, make), an Actor (a logical subject or an agent) and the Goal of the performed action. These processes express the notion that something or an entity (through a process of 'doing' or 'acting') does something which may in turn be done to some other entity.

b. Mental Processes. These refer to processes related to thinking, feeling and perceiving. They are realized by A Perception Verb (e.g. see, look), cognition (think, believe, convince, know), desideration (e.g. want, hope, wish) and emotion /affection (e.g. feel, like, please, fear, wonder). Two participants are involved in these processes: a Senser (a person who senses) and a phenomenon (the object involved in the process or what is sensed, felt or seen).

c. Relational Processes. These are processes expressing 'being' (e.g. Sarah is wise) or 'having' (e.g. Peter has a piano). The central meaning of this type is 'something is $\mathrm{x}$ '. These processes fall into two subtypes: Attributive (e.g. John is rich) and Identifying (e.g. John is the richest). The two participants involved in the attributive processes are a Carrier and an Attribute and those involved in the identifying processes are an Identified and an Identifier.

d. Verbal Processes. These are processes of 'saying' or exchanging information and meaning. They enact human experience in a form of language. They are realized by some verbs like 'say', 'claim', 'talk', 'describe', 'praise', etc. These processes involve two participants; a Sayer and a Receiver (e.g. Mary told (sayer) told us (the truth).

e. Existential Processes. These processes indicate that something exists (There was a storm) or happens (There was confusion, shouting and breaking of chairs in the parliament hall). What set this type of processes from the other ones is that the subject is not a participant but the item 'there' which indicates the feature of existence or what exists rather the participant that exists (it has no representational function). The phenomenon (be it a person, thing, object, institution or abstraction) being said to exist is called the Existent.

\section{Methodology}

The present study presents a critical discourse analysis which is based on van Dijk's and Halliday's framework. The analysis thus operates on both micro and macro levels. As it can be noted from the earlier account on the 'Ideological Square' theory, van Dijk adopts an approach which is less oriented to linguistic forms and is more focused on social variables such as power and ideology. In contrast, Halliday's model relies much more on linguistic textual analysis, focusing on lexico-syntactic elements. While CDA provides a textual analysis with an ideological dimension focusing on social variables such as power and ideology, SFG complements such a critical perspective by providing linguistically oriented insights into the social function of a particular discourse (Clarence-Fincham, 2001, p.25). Accordingly, SFG serves as a powerful tool for providing a detailed textual linguistic analysis which CDA might lack. Hence, the adoption of both approaches for the purpose of textual analysis relates the linguistic dimension with the social one. Put it another way, this methodology combines the micro-pattern (local semantics) in a text with the macro-patterns of culture and society.

The analysis proceeds through four stages. The speeches are first divided into separate excerpts according to themes embedded in them. Then, the excerpts related to the same identified theme are put together and parsed into separate clauses. All clauses in each theme discourses are then subjected to transitivity analysis identifying the types of processes and participant roles forming each clause. The following chart presents the stages of the analysis. 


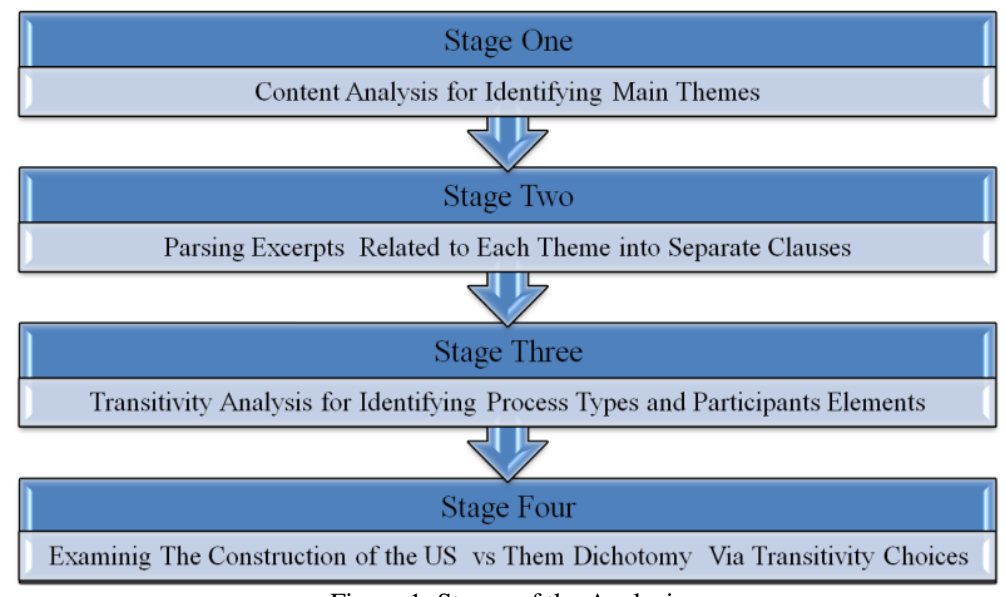

Figure 1. Stages of the Analysis

Analyzing transitivity structures of the speeches has ended the researchers to identify the process types predominate in the speeches (material, mental, verbal, relational, existential). The analysis has also highlighted the exact processes associated with different participants (the Self/ in-group (Israel/Palestine) Other/out-group (Israel/Palestine) and in connection to the theme each participant has assumed a particular role- associated with a particular process. The analysis is meant to reveal how the ideological standpoints of the two speakers are manifested in the representation of the Self/in-group and the Other/out-group through the transitivity structures in the discourse of both speeches.

In other words, the analysis shows how certain grammatical patterns and structures within SFG go in line with the general discourse strategy of positive self-presentation and negative other -presentation in van Dijk's 'Ideological Square'.

\section{ANALYSIS}

A content analysis of the speeches has revealed two main shared themes developed therein in relation to the Gaza War (2014). These themes are (1) Victimhood and (2) Self-power and Self-Defense. Below is a detailed analysis of the construction of the Self and Other in relation to each one of the two themes.

\section{A. Netanyahu's Speech}

The following figure presents the frequency of the processes used to represent the Self (Israel) and Other (Hamas) in Netanyahu's speech.

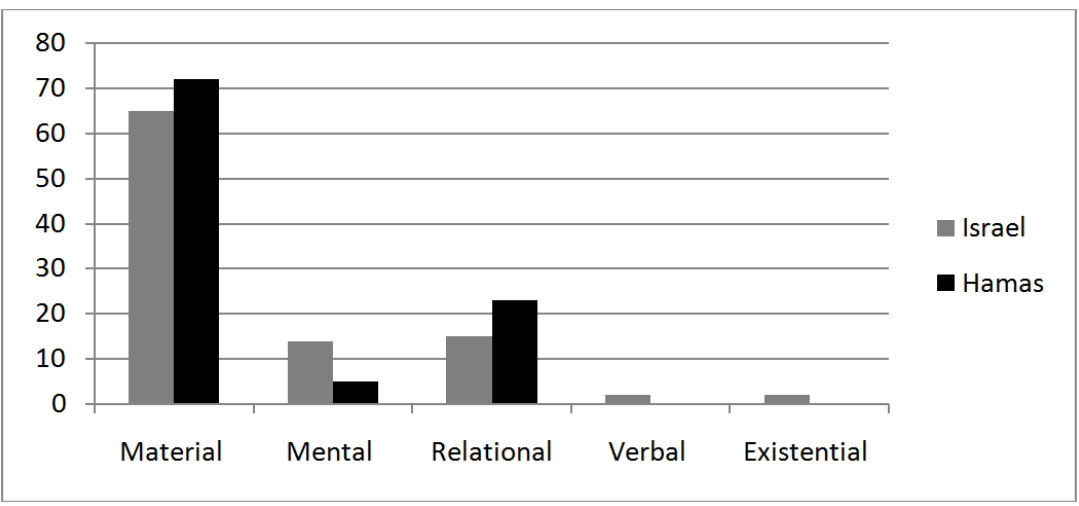

Figure 2. Processes of the Self (Israel) and Other (Hamas) in Netanyahu's Speech

Expectedly, the Material processes (verbs of acting and performing) dominate Netanyahu's speech taking precedence over other process types. This indicates that the speech places more emphasis on the actions of the Self/in-group and the Other/out-group. The material processes representing Israel and Hamas accounted respectively for 65 percent and 72 percent of the material processes. However, as it can be noted from the percentages there seems to be more emphasis on the actions of the Other. Similarly, the number of the relational processes (verbs of attributes and possession) depicting the Other (accounting for 23 percent) exceed those representing the Self (accounting for 15 percent). In contrast, the number of the mental processes (verbs of cognition/affection/wants) describing the Self (accounting for 14 percent) are more than those representing the Other. As far as the other minor verbal (verbs of saying) and existential processes (verbs of existence) are concerned, it seems that these processes are used only to depict the Self. 
In his speech, Netanyahu continually exposes all that is positive about the Israeli in-group and all that is negative about its opponent, Hamas. He first presents Israel as a victim of Hamas' attacks and then proceeds to depict Israel as being extremely powerful and highly glorified as shown below.

Victimhood Theme

One of the main themes permeating the discourse of Netanyahu's speech is that of Victimhood. Netanyahu emphasizes the suffering of the Israeli people during the Gaza war (2014) and the challenges they faced. In his speech, Netanyahu emphasizes the negative deeds of the Other and so expose his in-group's victimhood.

The processes through which this theme is presented are mostly material. They depict Israel as a victim of Hamas' violations and attacks during the war.

1. Hamas fired thousands of rockets at Israel

2. terrorists (Hamas) fire rockets at ... cities with impunity

3. terrorists (Hmas) dig dozens of terror tunnels under ... borders

4. to infiltrate ... towns in order to murder and kidnap ... citizens

5. Hamas cynically used Palestinian civilians as human shields

6. Hamas embedded its missile batteries in residential areas

As it can be noted from the examples (1-4), Hamas is presented as an active agent of atrocious acts firing rockets at Israel, kidnapping and murdering the Israeli people. Israel, on the other hand, is constructed as a passive recipient of such violent action carried out by Hamas. Furthermore, Hamas is depicted as also causing harm to the Palestinians by using them as human shields (5-6).

7. Israel justly defended itself against both rocket attacks and terror tunnels

8. As Israel surgically struck at the rocket launchers and at the tunnels,

9. Palestinian civilians were tragically but unintentionally killed

10. Israel dropped flyers, made phone calls, sent text messages, broadcast warnings .... always to enable Palestinian civilians to evacuate targeted areas

11 . We deeply regret every single civilian casualty

The material processes associated with Israel, however, place it into a sharp contrast with Hamas. Israel's actions during the war are depicted as defensive ones (7).

Thus, through the material processes, the Other/out-group is presented as an active agent of destruction while the Self/in-group as an agent of self-defense. This construction of the Self/in-group and Other/out-group is in line with van Dijk's "ideological Square" theory whereby the Self/in-group is presented with positivity while the other with extreme negativity.

Even when the Self/in-group is assigned the role of active agency in negative material processes entailing violence, its negative acts are de-emphasized through the use of euphemisms. The circumstance of manner "surgically" used in connection with the material process "struck" indicating the killing of the Palestinians (8) downtones the harshness of this act and lends some justification to the Israeli actions (8). Thus, the violent acts of the Self/in-group are justified as being righteous and reactional.

In the same vein, the Israeli launched attacks at Gaza are backgrounded through the use of agentless passive material process as in "Palestinian civilians were tragically but unintentionally killed" (9).

Further, the de-emphasis of the Self/in-group's negative actions is also realized through some other mental and material verb processes. The successive material process verbs associated with Israel in "dropped flyers", "made phone calls", "sent text messages" and "broadcast warnings" (10) represent the Self/in-group as being protective and considerate of the lives of civilians.

The Self/in-group is also represented as being the Senser participant of the mental process "regret" in relation to the killing of civilians (11). The choice of this mental process indicating feelings of sadness and pity over the killing constructs the Self/in-group as virtuous and human. Through these transitivity structures, the Self/in-group is depicted as an honorable and human that cares about the safety of civilians and wants to protect itself and other people from the danger posed by Hamas.

The dichotomy between the Self and the Other is further emphasized through parallel transitivity structures, probably to sharpen Netanyahu's perspective of the moral difference between Israel and Hamas.

12. Israel was doing everything to minimize Palestinian civilian casualties

13. Hamas was doing everything to maximize Israeli civilian casualties and Palestinian civilian casualties

14. Israel was using its missiles to protect its children

15. Hamas was using its children to protect its missiles

A close examination of the examples 12-15 reveals that the sharp contrast between Israel and Hamas with regard to their actions in the Gaza War is reflected in the construction of the Self/in-group and the Other/ out-group through alternating parallel transitivity structures. This places the Self/ in-group into sharp contrast to the Other/ Out-group. The Self/in-group is positively presented as minimizing the killing of civilians while the Other/ out-group maximizing it (12-13). The group polarization is realized through presenting the Self/ in-group and the Other/ Out-group as being involved in material processes that are semantically each other's opposites as in "maximize" and "minimize". A similar 
presentation of both groups is made through the use of the material clause "using its missiles to protect its children" in parallel contrast to "using its children to protect its missiles" (11-12).

16. Israel also faced another challenge

17. We faced a propaganda war

18. Jewish people have been demonized with blood libels and charges of deicide

19. The Jewish state is demonized with ... charges of genocide

The transitivity structures in the discourse of Victimhood also depict Israel as a victim of biased charges of targeting civilians and genocides. Examples 16-19 show further manifestations of the in-group's suffering and victimhood. Israel is not only depicted as a victim of Hamas' attacks this time but also of a propaganda war and biased criticism.

Netanyahu accentuates his in-group's victimhood by emphasizing the UN Human Rights biased and contradictory position from the Gaza War.

20. Israel is a tiny country (Identifying)

21. Yet nearly half, nearly half of the UN Human Rights Council's resolutions focusing on a single country have been directed against Israel

22. Israel, which took unprecedented steps to minimize civilian casualties, Israel is condemned

23. Hamas, which both targeted and hid behind civilians - that a double war crime -Hamas is given a pass

As is clear, the transitivity structures present Israel as a victim of the UN Human Rights Council's resolutions. The construction of Israel through a relational identifying process as a small country (20) emphasizes the in-group's victimhood. Furthermore, the material passive process in example 21 construes Israel as a helpless and passive participant upon which the injustices practiced by the UN are inflicted.

The contradiction in the position of the UN Human Rights Council is further emphasized by sharpening the contrast between the Self/in-group and Other/out-group. Again through comparisons and parallel transitivity structures and semantic opposites, the profound moral difference between the Self/in-group and Other/out-group is emphasized (22 23). The Self/in-group is depicted as 'virtuous' holding the highest moral values during the war while the Other/outgroup is depicted as an 'evil enemy' using civilian as human shields. These structures in turn intensify the Self/ingroup's victimhood. They include a condemnation of the UN position from Israel during the Gaza War. Israel that took steps to save civilians is condemned by the UN Human Rights Council for committing war crimes while Hamas that used civilians as a human shield is given legitimation.

Analysis of the transitivity structures in which the Other/out-group is involved reveals display further manifestations of negative other-presentation. Netanyahu depicts Hamas as a serious threat not only to Israel but to the whole world. This is achieved by positioning Hamas within the category of "Militant Islam". This presents Hamas as a global threat, because in his speech, Netanyahu refers to various terrorist out-groups (e.g, al Qaeda, ISIS, Hezbollah, Nusra) all of which are interrelated and categorized /classified under the umbrella of "Militant Islam". This is further highlighted by drawing a correlation between Hamas and 'Militant Islam' and thus presenting them as one cohesive unitary enemy. The transitivity structures in the discourse of Netanyahu's speech present 'militant Islamists' and Hamas as being one camp that share the same goal, i.e, to dominate the whole world.

24. Hamas's immediate goal is to destroy Israel (identifying)

25. But Hamas has a broader objective (attributive)

26. Hamas shares the global ambitions of its fellow militant Islamists

27. Their ultimate goal is to dominate the world (attributive)

The relational identifying process depicts Hamas as a hard enemy setting the destruction of Israel as its main goal (33). Hamas is further presented as a global threatening enemy with a broader goal of dominating the whole world (25 and 27). The threat of Hamas is presented as stemming from sharing the same global goals of militant Islamists. The material process "share" in (26) creates an adequation between Hamas and 'militant Islamists' and so places them in the same boat of enmity and threat.

As van Dijk (1991) indicated, parallelism is commonly adopted to "emphasize negative properties of opponents" (p. 219). A noticeable function of parallelism in this case is to adequate the negative properties of the out-groups. As Hodges (2007) put it "adequation is a tactic not only used by a group to identify itself, but used from an outside position of power to impose sufficient sameness on others for political purposes" (p.83).

The notion of 'militant Islam' is repeatedly juxtaposed with the necessity of sharing efforts to defeat Hamas. This designates Netanyahu's intention to elicit support for Israel's fight against Hamas. The construction of Hamas as a global threat serves to make the fight against Hamas a subject of concern for the international community as a whole. This act of globalizing the out-group's threat and this imposed adequation go in line with the general strategy of negative Other-presentation within van Dijk's 'ideological Square'.

Self-power and Defense Theme

After emphasizing the in-group victimhood and aggravating the out-group's threat, Netanyahu shifts toward another theme of power and self-defense. The Israeli in-group is placed in defiance against its enemies. A sense of power is constructed and the in-group is no longer positioned as a victim.

28. Today we, the Jewish people, have the power to defend ourselves

29. Israel be able to defend itself by itself against any threat 
30. We will defend ourselves against our enemies on the battlefield

31. We will expose their lies against us in the court of public opinion

32. Israel will continue to stand proud and unbowed

A careful analysis of the transitivity structures in this discourse of power shows that Israel is constructed as a capable self that has the power to defend itself. The relational processes associated with the Self/in-group depict Israel as being in possession of self-defense power (28) and as being strong and competent with self-derived power (29)

The depiction of the Self/in-group as being endowed with power is also realized through other material processes. The material clauses "defend ourselves", "expose their lies" and "continue to stand" exhibit the Self/ in-group as an influential, steadfast and strong Agent in the face of enemy (30-32).

The developing escalating construction of the self-power theme is finally accumulated with glorifying the Self. In Netanyahu's speech the general strategy of positive self-presentation is implemented by praise and positive references to the country of Israel, its history, its religion and its people.

33. In Israel, we have a record of making the impossible possible

34. We've made a desolate land flourish

35. We have used the fertile minds of our people to turn Israel into a global center of technology and innovation

36. Isaiah, our great prophet of peace, taught us nearly 3,000 years ago in Jerusalem to speak truth to power

The glorification of the in-group is realized through both Relational and Material processes. The Self/in-group is presented as being involved in positive identifying relational process of possession. The Self/in-group is identified as being in possession of "a record of making the impossible possible" (33). The semantic contrast expressed through the use of "the impossible" and "possible" construes the Self/in-group as highly influential. Similarly, the use of the nominal group "desolate land" in contrast to "flourish" within the material clause in which the Self/in-group is involved places it in charge of positive actions. The embedded implied metaphor of plantation and growth in "desolate land flourish" (34) and "fertile minds" (35) also plays a contributing role in this respect. They represent the Self/in-group as being a great achiever that is highly glorified.

Moreover, the Self/in-group is positively projected through material processes as a global center of technological innovation (35) and a beacon of truth and wisdom (36).

\section{B. Abbas's Speech}

The following figure presents the frequency of the transitivity processes used to represent the Self (Palestine) and Other (Israel) in Abbas's Speech.

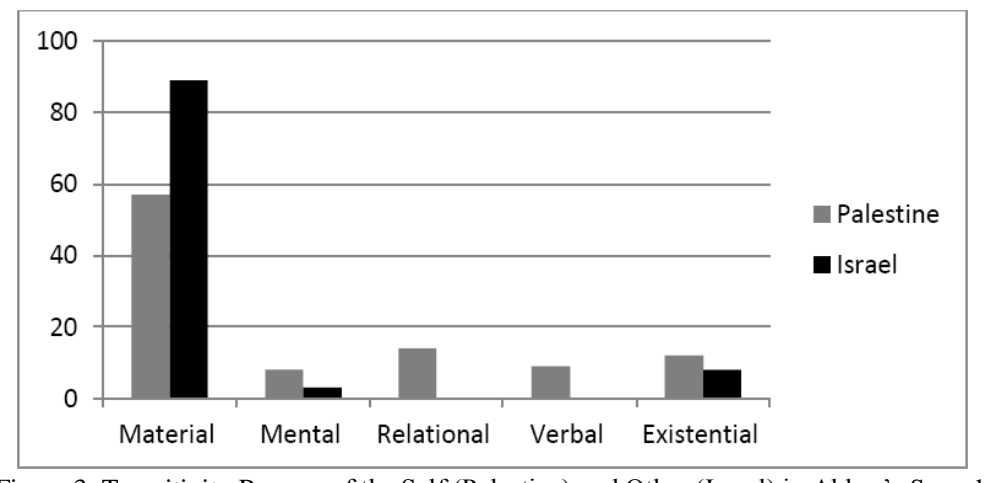

Figure 3. Transitivity Process of the Self (Palestine) and Other (Israel) in Abbas's Speech

A note on figure 3 shows that the material processes (verbs of acting and performing) representing the Self and Other dominate Abbas's speech. This indicates that the transitivity structures of the Self and Other in the speech gives much more focus on their actions. However, a comparison between the percentages of the material processes of the Self (accounting for 57 percent) with those of the Other (accounting for 89 percent) indicates that there is much more emphasis on the actions of the Other. However, a far as the mental (verbs of cognition/affection/wants) and existential (verbs of existence) processes are concerned, it is the processes associated with the Self that have a higher percentage accounting respectively for 8 percent and 12 percent in contrast to those processes associated with the Other and accounting for 3 percent and 8percent. Moreover, the relational (verbs of being and possessing) and verbal processes (verbs of saying) adopted in the speech are only used in the depiction of the Self.

Like Netanyahu, Abbas accentuates his in-group's victimhood and emphasizes the out-group's threat. He presents his in-groups (the Palestinians) as victims both in the past and present. His speech presents Israel as an existential threat to both the Palestinians and peace. He finally exposes the power of his Palestinian in-group and their right of self defense and glorifies their deeds as shown below.

Victimhood Theme 
Abbas commences his speech by conjuring the suffering of the Palestinians since Al-Nakaba ${ }^{1}$ of 1948 till the present time. In his account on the Gaza War (2014), Abbas presents the hard experiences of the Palestinians during the War as only one part of a prolonged history of an ongoing suffering. The accentuation of the in-group's victimhood and suffering is manifested in some transitivity structures which construe the Self/in-group (Palestinians) as victims of the Other/out-group's (Israeli) atrocities along the history both in the past and present.

1. In this year, in which this Assembly... conveyed the world's yearning .......in order to rectify the historic injustice inflicted on the Palestinian people in Al-Nakba of 1948

2. the occupying Power has chosen to defy the entire world by launching its war on Gaza

3. its jets and tanks brutally assassinated lives and devastated the homes, schools and dreams of thousands of Palestinian children, women and men

4. here we are again today

5. Here we find ourselves, full of grief, regret and bitterness raising the same long-standing conclusions and questions after a new war,

The transitivity structures in the discourse of Victimhood portray the Self/in-group (Palestinians) as victims both in present time and past history. The construction of the Self within the passive voice structures presents it as a helpless and passive participant upon which the injustices and miseries of Al-Nakba are inflicted (1). The Self/out-group is assigned the role of the Recipient or the Patient affected by Material process entailing enforced suffering (as in the verb 'inflicted on').

The transitivity structures associated with the Other/Out-group, however, presents Israel as a defiant and aggressive enemy. The use of the material process 'has chosen' in connection with that of 'defy' (2) entails its deliberate and aggressive acts against the Palestinians. Furthermore, the construal of Israel's defiance against the whole world as a choice depicts Israel as an arrogant entity endowed with a volitional power. Moreover, the Other/Out-group is depicted as a brutal enemy murdering lives and causing destruction (3).

The contrast in roles assigned to both groups brings the Self/in-group's victimhood into much focus and exposes the crimes and atrocious acts of the Other/out-group. This goes in line with the general strategy of negative otherpresentation in van Dijk's "Ideological Square".

The relational processes in which the Palestinians are involved project them as victims of repeated and continued suffering. After a third new war launched against Gaza, the Palestinians once again find themselves "full of grief, regret and bitterness". This is reinforced through the use of the adverb of frequency 'again' indicating the repeated occurrence of the action (4) and adverb of time 'still' (7).

Abbas continues to show that the difference within the cycle of the Self/in-group's suffering is that the consequences of the Israeli occupation are much greater in the present time after the last War on Gaza (2014). This places further emphasize on the Self/in-group's victimhood.

9. The difference today is that the scale of this genocidal crime is larger (Attributive)

10. and that the list of martyrs, especially children, is longer (Attributive)

11. and that dozens of families have been completely decimated

12. The difference today is that approximately half a million people were displaced from their homes

13. and that the number of homes, schools, hospitals, public buildings, ... mosques, factories and even cemeteries destroyed is unprecedented

14. And, the difference today is that the devastation caused by this recent aggression is unmatched in modern times,

15. we face a formidable challenge to reconstruct what has been destroyed by the occupation.

Again, the Self/in-group is presented as being a victim of much larger scale of crimes in the present time. The overgrowing consequences of the Israeli crimes against the Palestinians are emphasized through comparison, repetition and parallelism (parallel syntactic structures).

Analysis of the transitivity structures reveals that the Relational processes used in this discourse depicts the Self/ingroup as experiencing a growing amount of trauma and grievances in the present time. This is realized through the attributive comparative clauses involving implied comparisons between the past and present suffering of the Self/ingroup (9-10). In the same vein, crimes committed against the Self/in-group are described in terms of circumstances of manner and attributive adjectival clauses entailing an unmatched and aggravated scale. Thus, families "have been completely decimated" (11), and the scale of destruction and devastation is "unprecedented" and "unmatched" (13-14).

The growing suffering of the Self/in-group in present time is further reinforced through the repeated occurrence of the expression "The difference today". Moreover, the presentation of the suffering in terms of parallel transitivity structures brings it into more focus and intensifies the sense of in-group's victimhood (9-14).

The Self-group/in-group is further presented through material processes as a victim of the future challenges of rebuilding of what has been destroyed by the Other/ out-group. The Self-group/in-group is, hence, depicted as a victim of destruction (15).

\footnotetext{
1 "Al-Nakba" (Plight) is a popular broad term used in reference to the establishment of the State of Israel and the disastrous consequences of the 1948 war which led to the expulsion of thousands of Palestinians from their homes (Sadi and Abu-Lughod, 2007). The term summarizes and foregrounds the Palestinian suffering and presents the Israeli statehood as a catastrophe.
} 
Thus, the Self/in-group through the transitivity structures in Abbas's discourse is projected as a helpless victim of continued suffering in the past, present and the future.

In this same discourse of victimhood, the Palestinians are presented as peace seekers while at the same time Israel is depicted as a peace destroyer. The Palestinians are continually depicted as strongly devoted to the negotiations of peace while Israel is presented as renouncing any peace offer.

15. Even as we watched the ongoing and escalating Israeli violations, we exercised unimaginable self-restraint, silencing our cries and tending to our own wounds in order to give the American efforts the best possible chance for success

16. However, and as usual, the Israeli government did not miss the opportunity to undermine the chance for peace

17. Israel refuses to end its occupation of the State of Palestine since 1967, but rather seeks its continuation and entrenchment,

18. (Israel) rejects the Palestinian state and refuses to find a just solution to the plight of the Palestine refugees.

19. Israel has confirmed during the negotiations that it rejects making peace with its victims, the Palestinian people

It is notable that the choices in transitivity structures construct the Self/in-group as struggling for attaining peace. The Material processes associated with the Palestinians constructs the Self/in-group as an active Agent who is making great sacrifices for the sake of peace (15). This collectively, emphasizes the Palestinian victimhood and presents their commitment and contribution for peace as extremely great and sacrificial.

In contrast, Israel is presented throughout this discourse as standing in opposition to peace. This is manifested in the involvement of the Other/out-group in negative material processes. The material processes "undermine" (16), "refuses" (17) and "rejects" (17-18) construe the Other/out-group as a malicious enemy that despite peace offer and negotiations acts with refusal and rejection. The material clause in "did not miss the opportunity to undermine the chance for peace" depicts the Other/out-group as an active agent that snipes and targets any chance for peace (16).

Such dichotomy established through the transitivity structures of the Self/in-group and Other/out-group in Abbas's speech is in line with van Dijk' "Ideological Square". The transitivity choices in Abba's discourse serve to emphasize the positive deeds of the Self/in-group and those negative ones associated with the Other/out-group.

Abbas continues to present Israel as an eminent threat. Abbas warns that Israel is causing a new Nakba for the Palestinians by launching a third new war against Gaza.

20. I have addressed you (UN) in this hall during similar days in 2012 and cautioned that the colonial occupying Power was preparing for a new Nakba against the Palestinian people

21. I appealed to you (UN): Prevent a new Nakba

The transitivity structures in this context of threat construct the Other-out-group as posing extreme danger to the Self/in-group. The Other-out-group is depicted through material process as a malicious destructive entity causing much more suffering for the Palestinians (20). The involvement of the Self (represented by Abbas) in verbal processes indicating warning casts urgency on the matter and intensifies the in-group's victimhood (20-21). Moreover, describing the third last war waged against Gaza as a "new Nakba" intensifies and aggravates the scale of the Israeli threat posed against the Palestinians.

In this same discourse of Victimhood, Abbas presents Israel as posing a great threat to the lives of the Palestinians and their national authority presenting it as almost continually prone to violence and terrorism.

22. Over the past years, the occupying Power has pursued a policy aimed at deliberately weakening the Palestinian National Authority to undermine it and, in essence, to fully negate its role

23. When our efforts to end the internal division through national dialogue succeeded ... and we prepared to restore the unity of our land, nation and institutions ....all countries of the world welcomed this achievement, with the exception of Israel which has constantly sought to fragment our land and our national unity

24. The occupation's campaign specifically targeted the City of Jerusalem and its inhabitants, attempting to artificially alter the spirit, identity and character of the Holy City

25. At the same time, racist and armed gangs of settlers persisted with their crimes against the Palestinian people, the land, mosques, churches, properties and olive trees

26. This culture of racism (settlers), incitement and hatred was glaringly manifested in the despicable, appalling crime committed months ago by fascist settlers, who abducted the young Jerusalemite boy Mohammed Abu Khdeir, burnt him alive and killed him

29. It requires, in this context and as a priority, bringing an end to the Israeli occupation of our country, which constitutes in its practices and perpetuation, an abhorrent form of state terrorism and a breeding ground for incitement, tension and hatred.

Analysis of the transitivity structures in this discourse of victimhood and threat construct the Other/out group as an agent of destruction while the Self/in-group as helpless victim. The material verbal process "pursued", "insists", "sought", "undermine", "negate" and "targeted" (22-23) used in connection with the Other/out-group construe Israel as an aggressive entity which sets the crimes against the Palestinian as its main target. It is depicted as destroying lives, depriving the Palestinians of having national authority (22-23) and judaizing the holy city of Jerusalem (24). The circumstances of manner "deliberately" and "constantly" (22 and 23) associated with the Other/out-group's act reinforces the sense of threat and present it as being continuant. Moreover, the Other/out-group is presented as greatly 
threatening through the use of the material verb process "restore" in contrast to "fragment" (23). Hence, while the Palestinians are making efforts to restore the unity of their land, Israel is seeking to fragment it.

Through the analysis it has been noted that the threat of Israel is further exposed by the adoption of pronominal adjectives with negative overtones in relation to the Other/out-group.This is revealed in the negative loaded words and phrases (involving meanings beyond the literal one) denoting the out-group (the Israeli settlers) and their actions. The Israeli settlers are repeatedly identified as 'racist' and 'fascist' (25-26). Such loaded terms foreground the hostile attitudes of the settlers towards the Palestinians. This is further reinforced by the negative phrases "culture of racism, incitement and hatred". These discourse constructions present the Palestinian in-groups as innocent and defenseless victims of such a racist Israeli out-group's racist ideology and aggressive acts.

Furthermore, other transitivity structures present the Israeli out-group as an active agent of atrocities. The material verb processes "abducted", "burnt" and "killed" (26) depicts the Other/out-group as extremely brutal and murderous and so constructing it as a dire threat.

The construction of the Other/out-group's threat culminates with the depiction of the Israeli occupation as a source of extremism, terrorism, tension and hatred (29).

Self-Power and Self-Defense Theme

By the end of the speech, Abbas's discourse is directed towards another theme of power and defense. Abbas affirms that the Palestinians will not abandon their legitimate right to defend themselves.

30. we will not forget and we will not forgive and we will not allow war criminals to escape punishment.

31. The Palestinian people will continue their struggle and steadfastness

32. And will rise brave and strong from the rubble and destruction

33. I affirm in front of you that the Palestinian people hold steadfast to their legitimate right to defend themselves against the Israeli war machine and to their legitimate right to resist this colonial, racist Israeli occupation.

34. We, as our poet Mahmoud Darwish said: "are infected with an incurable disease, that is hope, and we love life if we are given the chance for it".

The Self/in-group is constructed through parallel successive material clauses as strongly holding a firm position against its opponent (30) and persisting on its struggle (31 and 32). The Self/in-group is further projected as insisting on its right of self-defense and resistance (33) and preserving itself by strongly hanging onto life and hope (34). The presentation of the Self/in-group as rising from "the rubble and destruction" (32) and as being "infected an incurable disease" of 'hope' (34) projects the Palestinian in-group as extremely powerful, resolved and dedicated.

Abbas proceeds on in his speech to affirm the right of the Palestinians to have peace and protection.

35. Palestine refuses to have the right to freedom of her people ... remain hostage to Israel's security conditions

36. We will not accept to forever be the ones being demanded ... to remain silent as they are killed and their land is stolen

Again the transitivity structures present the Self/in-group as 'strong' and 'defiant'. The Self/in-group is depicted through material processes as rising to their rights to freedom and security by facing the Other/out-group's violations with rejection and refusal (35and 36).

37. At the same time, I affirm that our grief, trauma and anger will not for one moment make us abandon our humanity, our values and our ethics;

38. we will always maintain our respect and commitment to international law, international humanitarian law and the international consensus,

39. we will maintain the traditions of our national struggle established by the Palestinian fedayeen and to which we committed ourselves since the onset of the Palestinian revolution in early 1965

In this same discourse of Self-power and defense, the Self/in-group is also glorified. It is represented through some material processes as human and honorable maintaining its values and ethics despite all challenges (37) and strongly committed to international law (38) and the traditions of its struggle (39).

\section{CONCLUSION}

This study provided a critical discourse analysis of the speeches of the Israeli Prime minister, Benjamin Netanyahu and the Palestinian President, Mahmoud Abbas to the United Nations General Assembly on the Gaza War (2014). The analysis is based on van Dijk's and Halliday's framework to examine the representation of the "Self" and "Other" in relation to the war. The results revealed that both speakers portray the Self/in-group as a beacon of strength, humanity and goodness in contrast to the Other/out-group that is depicted as bit hole of evilness. In the speeches, both speakers victimize their in-group and identify the out-group as an eminent threat. In trying to elicit support for their claims and agendas concerning the Gaza War (2014), they both expose and aggravate the negative acts and grievances of the outgroup.

A micro analytical reading of both speeches has uncovered some embedded ideological patterns. In the speeches, linguistic choices in the transitivity structures encode the ideological positions of each speaker projecting the strategy of positive-self presentation and negative-other presentation. The in-group in both speeches is continually inscribed as the Actor in material processes that construct the Self as an influential and committed agent seeking peace and defending itself against the danger and threat posed by the Other while the out-group is presented as an agent of negative acts. In 
the same vein, the out-group is presented through relational processes as an identified participant or a Carrier of negative attributes denoting violence and atrocity. Within these transitivity structures, embedded senses of threat, danger, in-group suffering and sacrifice are expressed and reinforced through the circumstances of manner. Moreover, the polarization pattern is also implemented in the speeches through parallel grammatical structures and polarized lexicalization (semantic contrast).

\section{REFERENCES}

[1] Alo, M. A. (2012). Rhetorical analysis of selected political speeches of prominent African leaders. British Journal of Arts and Social Sciences, 10. I, 87-100.

[2] Aschale, A. (2013). A critical discourse analysis of Barack Obama's speeches vis-à-vis Middle East and North Africa. Addis Ababa University. https://www.files.ethz.ch/isn/168385/CDA\%20of\%20PBO\%20in\%20ME\%20\%20NAfrica\%20\%20\%20By\%20Alelign\%20A\%20.pdf (accessed: 12/10/ 2016).

[3] BBC. (2015). Guide: Why are Israel and the Palestinians fighting over Gaza?. http://www.bbc.co.uk/newsround/20436092 $(10 / 6 / 2018)$.

[4] Fairclough, N. (1995). Critical discourse analysis: The critical study of language. New York: Longman.

[5] Hodges, A. (2007). The narrative construction of identity: The Adequation of Saddam Hussein and Osama bin Laden in the 'war on terror'. In A. Hodges \& C. Nilep (eds.), Discourse, war and terrorism ( $1^{\text {st }}$ edn). Amesterdam: John Benjaminspp, 6787.

[6] Iqbal, A. (2015). Discourse analysis of prominent politicians' public speeches: Pre and post-election 2013, Pakistan. Linguistics \& Literature Review I. 2, 1-14.

[7] Masalha, N. (2001). Expulsion of the Palestinians. Institute for Palestine Studies. http://www.robincmiller.com/pales2.htm (accessed 10/5/2018).

[8] Nazish M, Faraz A B \& G, Illahi. (2014). Critical analysis of political discourse: A study of Benazir Bhutto's last speech. Balochistan Journal of Linguistics 2.3, 79-95.

[9] Morgan, D. (2014). Recontextualising the 'war on terror': Discursive practices from Bush to Obama. E-International Relation Students. http://www.e-ir.info/2014/07/03/recontextualising-the-war-on-terror-discursive-practices-from-bush-to-obama/ (accessed: 20 /11/2016).

[10] Nejad, A. M., A. Pandian, O. Mahfoodh \& M. Shamsaddini. (2013). The representation of a presidential speech: A critical discourse analysis. Iranian EFL Journal 9.2, 167-179.

[11] Rahimi, F. \& M.J. Riasati. (2011). Critical discourse analysis: Scrutinizing ideologically-driven discourses'. International Journal of Humanities and Social Science 1.16, 107-112.

[12] Rashidi, N. \& M. Souzandehfar. (2010). A critical discourse analysis of the debates between republicans and democrats over the continuation of war in Iraq. JoLIFE 3.2, 56-77.

[13] Sanger, A. (2011). The contemporary law of blockade and the Gaza freedom flotilla. In L. Arimastu \& T. McCormack T (eds.), Yearbook of Internal Humanitarian. Berlin: Springer Science \& Business Media, 297-444.

[14] Sarfo, E. \& E. A. Krampa. (2012). Language at war: A critical discourse analysis of speeches of Bush and Obama on Terrorism'. International Journal of Social Sciences \& Education 3.2, 378-390.

[15] Van Dijk, T. A. (1991). Racism and the press. London: Routledge.

[16] Van Dijk, T. A. (1997). What is political discourse analysis?. In J. Blommaert \& C. Bulcaen (eds.), Political linguistics (2 ${ }^{\text {nd }}$ edn.). Amsterdam: John Benjamins Publishing Company, 11-52.

[17] Van Dijk, T. A. (1998). Ideology: A multidisciplinary approach. London: SAGE publications Ltd.

[18] Van Dijk, T. A. (2002). Political discourse and ideology. In C. U. Lorda \& M. Ribas (eds.), Anàlisi del discurs politic (1 $1^{\text {st }}$ edn). Barcelona: Universitat Pompeu Fabra, 15-34.

[19] Van Dijk, T. A. (2005). War rhetoric of a little ally: Political implicatures and Aznar's legitimatization of the war in Iraq. Journal of Language and Politics 4.1, 65-94.

[20] Van Dijk, T. A. (2006). Politics, ideology and discourse. Encyclopedia of Language and Linguistics. Oxford: Elsevier, 728-740

[21] Wang, J. (2010). A critical discourse analysis of Barack Obama's speeches. Journal of Language Teaching and Research 1.3, 254-261.

[22] Wikipedia. (2015). Israel-Gaza conflict. https://en.wikipedia.org/wiki/2014_Israel\%E2\%80\%93Gaza_conflict (accessed 11/6 /2018).

[23] Wikipedia. (2018). Fatah-Hamas conflict. https://en.wikipedia.org/wiki/Fatah\%E2\%80\%93Hamas_conflict\#cite_note fatah_vs_hamas-23 (accessed 11/5 /2018).

[24] Yu, F. (2011). A study of Bush's speech on Iraq: A CDA approach”. US-China Foreign Language. 9.6, 339-365.

\footnotetext{
Alaa' G. Rababah is a PhD student of Linguistics at the University of Jordan. Her academic research focuses on Critical Discourse Analysis and Cognitive Semantics. She is currently writing her Ph.D thesis in Critical Discourse Analysis in which she analyzes, contrasts and compares between Benjamin Netanyahu's and Mahmoud Abbas's Speeches to the United Nations General Assembly in the Context of the Israeli-Palestinian Conflict. She published a paper in Corpus Linguistics that appeared in International Journal of English Linguistics. In addition to her academic pursuits, she currently works as a full-time English lecturer at Al Balqaa Applied University, Jordan.
}

Jihad M. Hamdan is a professor of linguistics and translation at the University of Jordan. He obtained his PhD from the University of Reading, UK in 1994. He has published extensively in the areas of language acquisition, lexicography, discourse 
analysis, contrastive linguistics and translation. Many of his papers appeared in international and leading journals such as World Englishes, Babel, International Journal of Lexicography, Poznan Studies of Contemporary Linguistics and Journal of Psycholinguistic Research. Currently, he is the President of the Association of Professors of English and Translation at Arab Universities. He is also the Editor-in-Chief of International Journal of Arabic-English Studies. 